\title{
Agave and Opuntia Species as Sustainable Feedstocks for Bioenergy and Byproducts
}

\author{
José Amador Honorato-Salazar $^{1}\left(\mathbb{D}\right.$, Jorge Aburto ${ }^{2}$ (D) and Myriam Adela Amezcua-Allieri ${ }^{2, *(D)}$ \\ 1 Campo Experimental San Martinito, Instituto Nacional de Investigaciones Forestales, Agrícolas y Pecuarias \\ Carretera Federal Mexico-Puebla Km 56.5, Santa Rita Tlahuapan, Puebla 74100, Mexico; \\ ahonorato650@gmail.com \\ 2 Gerencia de Transformación de Biomasa, Instituto Mexicano del Petróleo, Eje Central Lázaro Cárdenas \\ Norte 152, Colonia San Bartolo Atepehuacan, Mexico City 07730, Mexico; jaburto@imp.mx \\ * Correspondence: mamezcua@imp.mx; Tel.: +52-55-91758496
}

Citation: Honorato-Salazar, J.A.; Aburto, J.; Amezcua-Allieri, M.A Agave and Opuntia Species as Sustainable Feedstocks for Bioenergy and Byproducts. Sustainability 2021, 13, 12263. https://doi.org/10.3390/ su132112263

Academic Editors: Barry D. Solomon and Hamid Rezaei

Received: 25 September 2021

Accepted: 3 November 2021

Published: 6 November 2021

Publisher's Note: MDPI stays neutral with regard to jurisdictional claims in published maps and institutional affiliations.

Copyright: (c) 2021 by the authors. Licensee MDPI, Basel, Switzerland. This article is an open access article distributed under the terms and conditions of the Creative Commons Attribution (CC BY) license (https:// creativecommons.org/licenses/by/ $4.0 /)$.

\begin{abstract}
Currently, Mexico is facing an energy transition, therefore updated policy regulations pertaining to the sustainable use of biomass are needed. In particular, policy that favors the sustainable use of biomass to produce energy and bioproducts to privilege climate change mitigation is needed. This review describes the use of maguey (Agave spp.) and nopal (Opuntia spp.; also known as "cactus") for biofuel production, especially in marginal areas. Emphasis is given on documented case studies discussing features of production and cultivation for both maguey and nopal, in addition to their potential for fuel production. Environmental and social sustainability issues in terms of waste value and new opportunities as bioenergy feedstocks and byproducts are also discussed. Although the paper does not deeply describe aspects of biomass transformation, such as bioprocess configurations, it gives characteristics of production in addition to cultivation. Agave and Opuntia species may represent a suitable feedstock for biofuels, bioproducts, bioenergy and biorefineries, especially in dry lands (semi-arid and dry sub-humid), deforested areas, agroforestry systems and agricultural semi-terraces known as metepantle in Mexico.
\end{abstract}

Keywords: Agave; bioenergy; biofuels; bioproducts; Opuntia; sustainability; waste to energy

\section{Introduction}

As the population continues to rise, there will be an increased demand for food, fibers, forage and renewable biomass resources for energy, biofuels and chemical products [1,2] The policy must encourage the sustainable use of biomass while also promoting climate change mitigation [3,4]. Furthermore, climate change will affect agro-ecological conditions, land suitability, crop yield, cropping area and land-use intensity [5,6]. Facing crop productivity and climate change challenges for food and bioenergy production, some approaches have been highlighted, such as using abandoned or unsuitable agriculture lands [7], arid and semi-arid lands [8], deforested areas, agroforestry system, especially in agricultural semi-terraces known as metepantle in Mexico [9,10]; use of plants with desirable traits of high productivity and low water consumption [11,12]; as well as engineered metabolic photosynthetic pathways [13,14].

Remote sensing has been used to determine the potential area of unoccupied (abandoned) agricultural lands that can be used for energy crop production. An earlier study found an amount between 385 and 472 million hectares [7]; a more recently study reported from 320 to 702 million hectares in China, Europe, India, United States, South America and Africa [15], accounting only for degraded and unoccupied cropland, vegetation land and mixed crop. However, it has been reported that approximately 12-14.6\% (1.6-1.9 billion ha) of the total world is arid and $12.2-18 \%(1.6-2.4$ billion ha) is semi-arid [16,17]. This land can possibly be available for energy crop without competing with food crops. The agroforestry system in semi-terraces (metepantle) are an ancient agricultural system where 
crops and vegetables are cultivated, and Agave species are used to divide the cultivations. They are used along Mexico in northeastern of Chihuahua State, Sonora valley, Tamaulipas's mountains, Mexico City's basin, Hidalgo, Michoacan, Puebla, Tlaxcala and Oaxaca States [18].

Diverse plant species within dry regions have been identified with high water-use efficiency and water shortage resistance since they exhibit a crassulacean acid metabolism (CAM) photosynthesis, such as Agave and Opuntia species, which have been recognized as sustainable bioenergy feedstocks $[11,14,18-23]$. One of the most remarkable traits of CAM plants is that they have their stomata open at night, thus allowing the initial fixation of $\mathrm{CO}_{2}$ during periods when conditions leading to evaporative water loss are at a minimum. During the daytime, the stomata are closed to reduce water loss and eliminate the possible net influx of $\mathrm{CO}_{2}$, and photosynthesis can proceed by using the reservoir of stored $\mathrm{CO}_{2}$. Under dry weather, the water supply is very limited. Therefore, CAM plants have adapted by permanently closing the stomata and stopping all gas exchange. CAM plants have the advantage of being able to retain and reused $\mathrm{CO}_{2}$ produced by respiration, thus preventing loss of carbon and helping to maintain a favorable dry weight through extended periods of severe drought $[24,25]$. In Mexico, a variety of Agave and Opuntia species are mainly found in natural populations in arid, semi-arid and dry sub-humid zones [26-28], covering an area of about $70 \%$ of Mexican territory [29].

A deep study of CAM plant metabolism has been carried out since the beginning of 21 century [30]. However, a small number Agave and Opuntia species, among other CAM species, have been undervalued and few investments in agricultural improvements have been made for most useful varieties of these species [31]. This paper presents a review of the current status of Agave and Opuntia species in Mexico and features of production and cultivation as well as their potential for biofuels and byproducts sustainable production. Waste valorization and new opportunities as bioenergy feedstocks are also discussed. The use of Agave and Opuntia biomass and residues to produce high value-added products deals with the aim of environmental and rural sustainable development, especially as they become highly attractive as new potential feedstocks in arid, semi-arid and dry sub-humid lands.

\section{Methodology}

The search of the literature on Agave and Opuntia species was performed in a broad and specific scope by first selecting the information related to the importance of the metabolism and growing interest in these species as bioenergy crops. Studies were also reviewed $[8,11,23,30,32-35]$ on its diversity, ecology, agronomy, biomass production and conversion into biofuels, productivity and the feasibility of growing these species in arid, semi-arid and marginal lands of southwestern USA, Mexico, Africa, Australia and other regions where experimental field trials of candidate species for energy crops or commercial crop production have been established. Information on these studies is given and analyzed throughout the sections of this paper.

The distribution of Agave and Opuntia species was addressed, including their productivity of experimental field trials and crop yield in Mexico and other countries. Then, an analysis was focused on the distribution, cultivated areas and production of these species in Mexico, indicating the main used species for cultivation and commercial purposes.

Detailed national data for the cultivated area and crop production from 2004 to 2019 were obtained from the Food, Agriculture and Fisheries Information Service [36]. Moisture content, fresh weight and different biomass proportion of the plants were used to estimate the production in dry weight and analyze the productivity.

Finally, the main chemical composition for some Agave and Opuntia species was summarized, followed by the review and analysis of the potential for both species as feedstock to produce biofuels, bioenergy and byproducts. 


\section{Agave (Agavaceae) and Opuntia (Cactaceae) as CAM Crops}

Species of Agave (Agavaceae) and Opuntia (Cactaceae), have increasing attention not only as a CAM species but also as energy crops $[8,12,14,18-21,37-41]$. As indicated previously, these plants are high water efficiency and are suitable for growing on abandoned, degraded agricultural lands or drylands where precipitation is scarce, thus helping to rehabilitate these degraded lands, combat soil erosion and desertification [4]. The traits and diversity of these species provide challenging strategies for agronomic practices and selection of appropriate cultivars to be grown as bioenergy crops, especially in rain-fed areas with low amount or frequency of precipitation where traditional food and bioenergy crops are unable to be cultivated $[9,26]$. Furthermore, both species can go along with $\mathrm{C} 3$ or C4 bioenergy crops.

In addition, Agave and Opuntia species produce comparable amounts of biomass comparing with $\mathrm{C} 3$ and $\mathrm{C} 4$ plants although with significantly lower inputs of water ( 80 and $20 \%$, respectively), and under optimal growing conditions, the dry mass productivity $\left(\mathrm{kg} \mathrm{ha}^{-1}\right.$ year $\left.^{-1}\right)$ of 43,000 is also comparable to C3 herbaceous species $(35,000)$, agronomic C4 species $(49,000)$ and trees $(39,000)[42]$.

The geographical location of Mexico allows it to receive daily large amounts of energy from the sun for both renewable energy and plant breeding. Then, Agave and Opuntia species are very appreciated for food, cattle feed and spirit production as tequila, mezcal and pulque, among others. Hence, there are dedicated cultivation land for intensified agriculture, but they are also small cultivation known as metepantle [5,6], which helps to separate the crops. Indeed, the application of sustainable land management (SLM) like metepantle diminishes desertification and help to recuperate and reintegrate land, soil, water and vegetation. Indeed, SLM refers to the multi-functional utilization of land instead of mono-functional land uses with increased yields by $30-170 \%$. However, only a holistic and stakeholder's engagement approach might develop local solutions [43].

\section{Characteristics of Production and Cultivation of Agave and Opuntia}

\subsection{Agave Species}

Agave is a large and most diverse genus in the family Agavaceae, which includes nine genera and approximately 340 species [44]. The genus Agave is divided into two subgenera, Littaea with flowers spicate in pairs, clusters or racemose and Agave with inflorescences of spreading umbellate or paniculate branches [42,45].

Agave is indigenous to the Americas, and is distributed from the southern United States to Colombia and Venezuela, including also all of the Caribbean islands, from the Bahamas to Aruba, Curaçao and Trinidad and Tobago [26]. Mexico is considered the center of origin [45], where about 261 species are found and 177 of these species are endemic [44].

Agave plants can almost be found throughout all Mexico from sea level up to $3500 \mathrm{~m}$ altitude, but they are most commonly found between 1000-2000 $\mathrm{m}$ altitude and in tropical deciduous forests, thorn forests, grasslands, deserts and chaparral and mixed oak-pine forests. They are very diverse in the arid and semi-arid zones of the North and Centre, but they diminish towards the humid and warm zones of the South [26,27]. The distribution of Agave species is shown in Figure 1.

Since pre-Hispanic times, Agave species have been very appreciated in Mexico and used as food, forage, fibers, beverages, medicine, fuel, shelter, ornament, fertilizer, tools, construction materials, living fences, among other uses $[45,46]$. The production of beverages from Agave plants is one of traditional uses that still prevails in Mexico and is now an important industry. One kind of beverage is drawn as sap from the living Agaves and consumed fresh as a beverage called aguamiel or fermented as pulque. Other kinds of beverages are the distilled liquors or spirits known as Tequila, Mezcal, Bacanora, Raicilla and Comiteco, which are made from the cooked Agave heart or globose core shape, called piñas in Spanish. Selected Agave species are harvested in Mexico for different purposes from natural populations, semi-domesticated cultivation or industrial intensive plantations. 


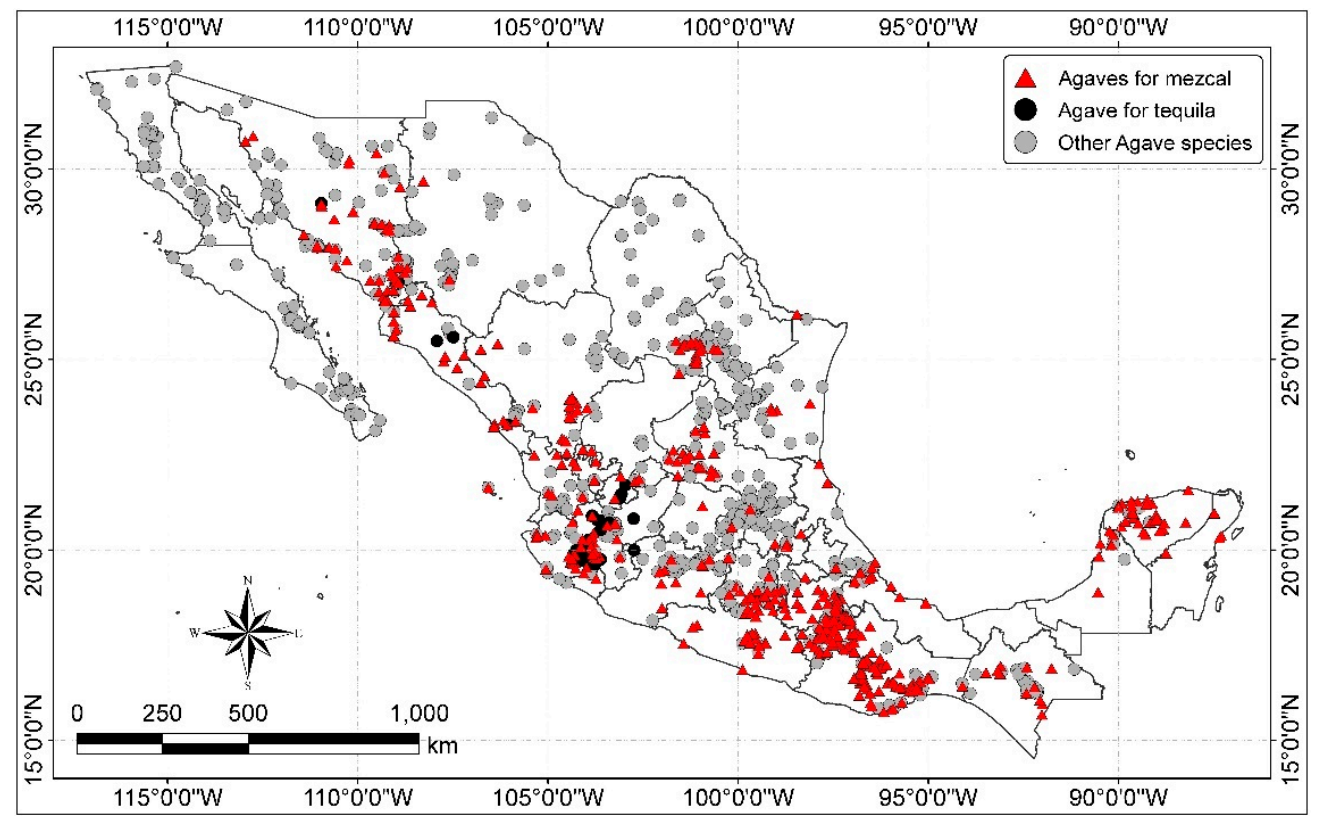

Figure 1. Distribution of Agave species in Mexico (map by the authors with data from CONABIO [47]).

There are at least 58 Agave species used for the production of beverages [46]. However, a few species are the most important. The principal Agave species for pulque production are Agave salmiana, A. mapisaga, A. atrovirens, A. ferox, A. hookeri and A. americana [46]. Tequila $(100 \%)$ is made exclusively from $A$. tequilana Weber variety blue [48]. About 35 species of Agave are used for making mezcal [49], but the most used are Agave angustifolia, A. americana, A. duranguensi, A. convallis, A. cupreata, A. inaequidens, A. karwinskii, A. rodacantha, A. macrocantha, A. marmota, A. canatala, A. potatorum, A. salmiana var. crassispina and $A$. crassispina var. culta $[50,51]$. Agave maximiliana, A. inaequidens, A. valenciana, A. angustifolia and $A$. rhodacantha are used for making Raicilla spirit [52,53]; Agave angustifolia for Bacanora spirit [54]; and Agave americana and A. salmiana for Comiteco spirit [55].

\subsection{Productivity of Agave}

Agave species have been introduced in China, Australia, Tanzania, Kenya, Madagascar, Brazil and across the Caribbean and Mediterranean areas for commercial use [37,56]. The global cultivation of Agave as crop is around 500,000 ha [56], and $80 \%$ is cultivated for fibers and $20 \%$ for beverages and some forage. The main commercial producers of Agave (Henequen) for fibers are Colombia, Mexico, Nicaragua, Philippines and Ecuador from 2003 to 2013, while Mexico is the principal commercial producer of Agave for beverages and possesses several origin denominations for cropping and production of such beverages. Industrial cultivation of Agave for biofuels production is still in development in some countries $[21,33,39,40,57]$.

In Mexico, some species of Agave are well established as mature crops that are cultivated almost throughout the country for the commercial production of distilled and fermented beverages, also for production of fibers in Yucatan State located in Southern Mexico. The cultivated area of Agave is variable from year to year due to the price and demand of alcoholic beverages and fibers as well as the pest attack on the Agave fields. The total cultivated area of Agave was 192,516 ha in 2004 of which 26,341 ha were in production (Figure 2), then in 2019 the cultivated and productive areas were 141,123 ha and 34,817 ha, respectively. 


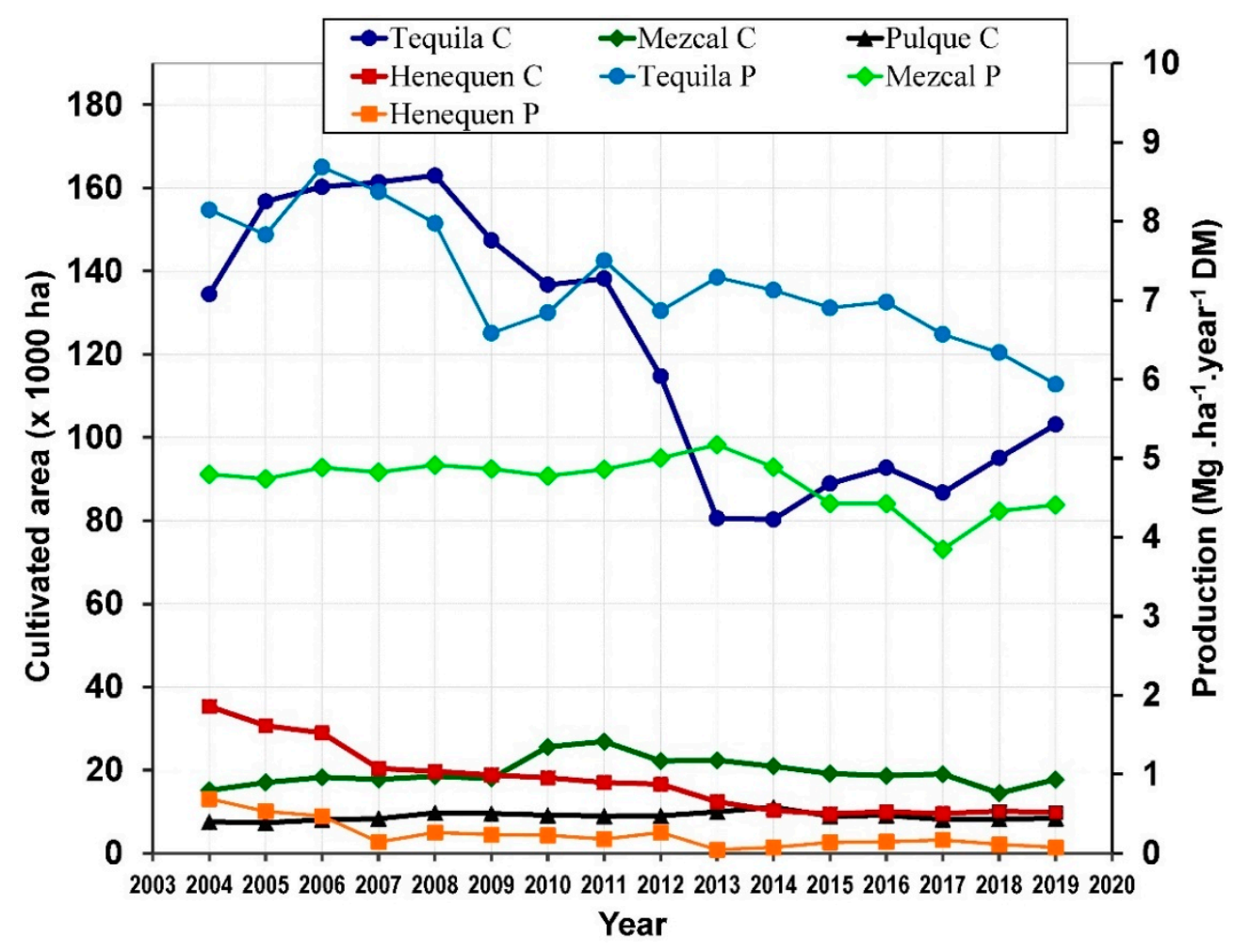

Figure 2. Cultivated (C) area and Production (P) of Agave in Mexico (Authors' elaboration with data from SIAP [36]).

The cultivated area decreased to 124,708 ha in 2014, but in the same year the productive area increased to 29,145 ha [36]. From 2004 to 2019, the average cultivated area of Agave was $72.6 \%$ for tequila, $11.7 \%$ for mezcal, $5.3 \%$ for pulque and $10.4 \%$ for fibers of the total cultivated area. Additionally, on average, $99 \%$ of the total cultivated and productive areas of Agave are rainfed and the remaining are irrigated fed.

Stems or heads of Agave are used for making Tequila or Mezcal, while the leaves are left as fertilizer in the cropping fields. The average proportion (\%) of fresh weight is 52.7 for stems and 47.3 for leaves, with a respective water content (\%) of 72.5 and 79.5 , respectively [58,59]. The production of Agave is reported in fresh weight of heads for Mezcal and Tequila, while Henequen production reports the fresh weight of leaves, therefore is possible to estimate the production in dry weight. Depending on the year of production (2004-2019), the total amount of dry matter (DM) produced by Agave plants was between $389,605,392$ to $878,903,316 \mathrm{~kg}$ for Tequila, from $66,120,968$ to $194,337,296 \mathrm{~kg}$ for Mezcal and from 2,007,123 to 56,843,821 for Henequen (Figure 2). Considering that on average the harvesting age of Agave is 6 years and that the production values are on accumulated biomass base, it is also possible to estimate the annual productivity $\left(\mathrm{kg} \mathrm{ha}^{-1}\right.$ year $\left.^{-1}\right)$, which is variable, 5936.4-8686.5 for Tequila, 3847.4-5171.8 for Mezcal and 44.8-688.4 for henequen.

Agave crops have annual biomass productivities $\left(\mathrm{kg} \mathrm{ha}^{-1} \mathrm{year}^{-1}\right)$ ranging from 4000 to 30,000 and may have even greater potential productivities, depending on the agronomic cultivation system [21,60-62]. The estimated annual productivity of Agave for Tequila and Mezcal is within the range of these reported values for Agave species. For comparison, productivity $\left(\mathrm{kg} \mathrm{ha}^{-1}\right.$ year $\left.^{-1}\right)$ of $\mathrm{C} 4$ photosynthetic species grown for biofuels such as maize, switchgrass and sugarcane range from 5000 to 26,000 [22].

Differences in productivity are attributed to the agro-ecological conditions where Agave is cultivated, such as day and night temperature, water availability, soil type, slope, climate, number of plants per ha, among other factors [62-64]. Agave spp. can be grown in poor dry areas [65]; however, there are some constrains for its widespread use that can be matched. For example, the damaging cycles of excess and shortage that the tequila industry 
have, in addition to the long time for Agave maturation and the habitat of flowering and exclusive morphology. It must also be considered the valorization of cut leaves, obtained through Agave harvest, or Jima in Spanish, besides the traditional use as fertilizer, other applications might give more certainty to a sustainable use of Agave [32,66].

According to SAGARPA [67] from 2017 to 2030, the total production of agave is expected to increase $30 \%$ in selected potential areas for agave plantations, which will benefit agave farms and producers under production contracts by leasing, share-cropping or tenant farming. Moreover, the current government policy is to help small rural farms ( $2.5 \mathrm{ha}$ ) by giving technical assistant and economic support to promote the well-being of farmers [68].

Niechayev et al. [22] developed an environmental productivity index in order to predict potential yields of A. americana in semi-arid and xeric regions, since it is expected to have extensive regions in the near future if climate change continues. The index might be useful to determine the potential geographic range for CAM species in the near future, such as warmer atmosphere, and larger changes in precipitation patterns.

\subsection{Opuntia Species}

The genus Opuntia belongs to the family Cactaceae and subfamily Opuntioideae, which, depending on the taxonomic classification, includes from 191 to 250 species [69,70]. Mexico is considered as well as the center of high diversity with approximately 83 to 104 species of Opuntia and over 50\% of its species are endemic [69,71]. The genus Opuntia is the most diverse and widely distributed in American continent from Canada to Patagonia; including all Central American, Caribbean and South American countries (Argentina, Bolivia, Brazil, Colombia, Peru and Venezuela). There are also species of Opuntia cultivated and naturalized in Australia, India, Algeria, Angola, Italy and South Africa [72,73].

The altitudinal distribution of Opuntia plants varies from below sea level up to $4500 \mathrm{~m}$ in the Andean uplands of Peru and Chile and from the desert to tropical regions of Mexico, where temperatures $\left({ }^{\circ} \mathrm{C}\right)$ are above 25 to -40 in Canada in wintertime [73]. In Mexico, species of Opuntia are found from sea level up to $3200 \mathrm{~m}$ with the major diversity between 1500 and $2500 \mathrm{~m}$ and they are predominantly distributed in semiarid and temperate climates, in disturbed areas of vegetation (agriculture lands), xerophytic shrub land, oak, pine-oak and oak-pine forest, and low tropical dry deciduous and semi-deciduous forest [28]. The distribution of Opuntia species in Mexico is showed in Figure 3.

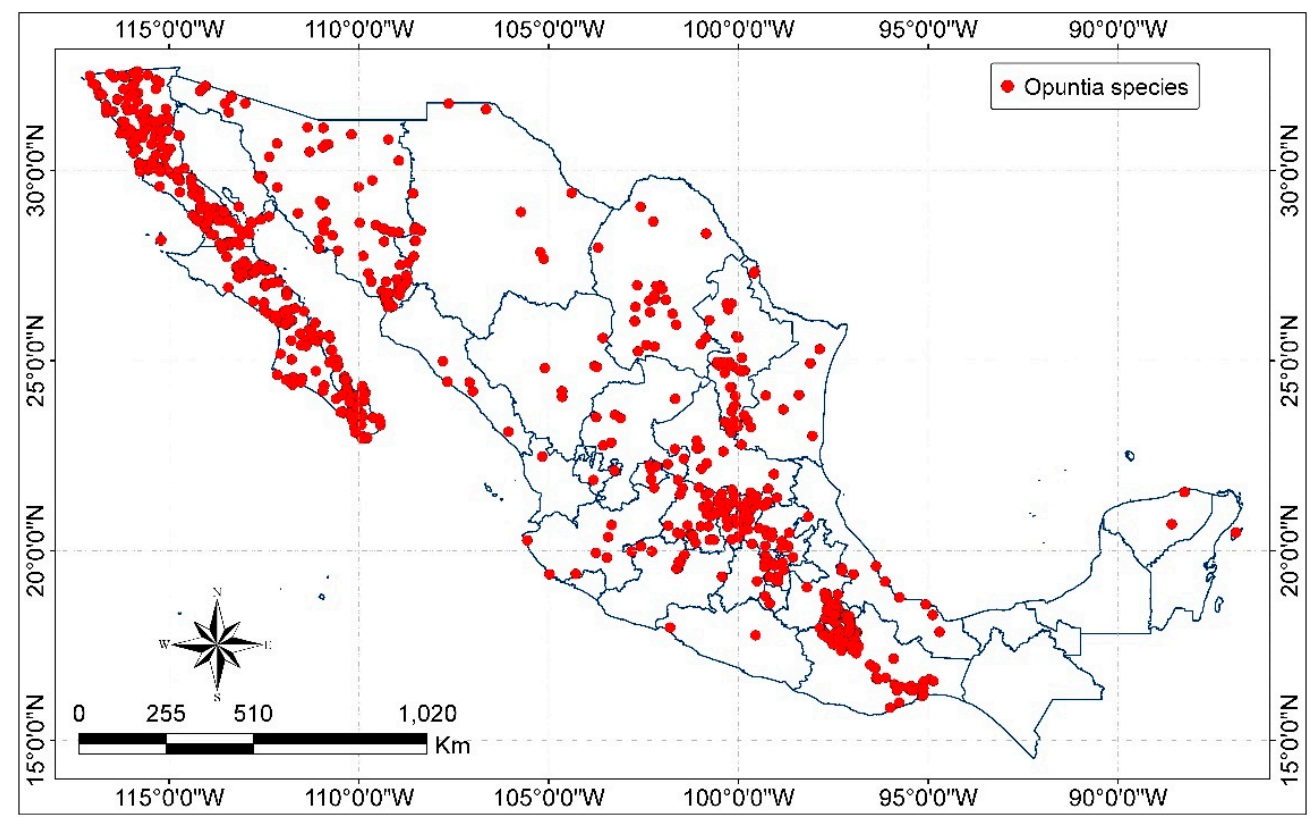

Figure 3. Distribution of Opuntia species in Mexico (map by the authors with data from CONABIO [47] and INEGI [74]). 
Since ancient times, Opuntia spp. have been recognized for a wide range uses. The tender cladodes (nopalli in Nahuatl, nopalitos in Spanish) are used as food, the mature cladodes are consumed for cochineal cultivation, and the prickly pear fruit is consumed fresh or fermented to prepare a prickly pear wine and sometimes used as medicine [69]. Currently, Opuntia species are used worldwide for producing fruit, vegetable, forage and cochineal breeding $[69,73]$; other uses and products derived from these plants have been summarized elsewhere [8].

In spite of the diversity of species of the genus Opuntia, only 10-12 species have been cultivated for different purposes. For fruit production, the species that are mainly used are: Opuntia ficus-indica, O. amyclae, O. xoconostle, O. megacantha and O. streptacantha. Although in Mexico another 8-15 species are considered for fruit production, wild species include Opuntia hyptiacantha, O. leucotricha and O. robusta [74-76].

In Mexico, the tender cladodes of Opuntia ficus-indica and O. amyclaea are used as a vegetable [73,77]. For forage production favorite species are O. ficus-indica, O. cantabrigiensis, O. lindheimeri var. tricolor, O. lindheimeri var. subarmata and O. imbricata [78], and at least 12 wild species [76]. For cochineal breeding Opuntia ficus-indica and O. cochenillifera (or Nopalea cochenillifera) are the preferred species [73].

\subsection{Productivity of Opuntia}

Cultivated or wild species of Opuntia can be found in about 30 countries over an area of around 1 million ha [56]. Most of cladodes production is for animal feed, for instance, about 400,000 ha in Brazil [73]. In Mexico, young cladodes are also harvested as vegetable for food intake. In fact, the cultivated area of Opuntia for vegetable and forage has followed an increasing trend from 2004 to 2019 [36]. In 2004, the cultivated surface (ha) was 10,208 for vegetable and 10,048 for forage, with a respective increase of 12,799 and 17,267 , respectively in 2019. In contrast, the cultivated area of fruit decreased from 52,144 in 2004 to 45,733 in 2019 (Figure 4).

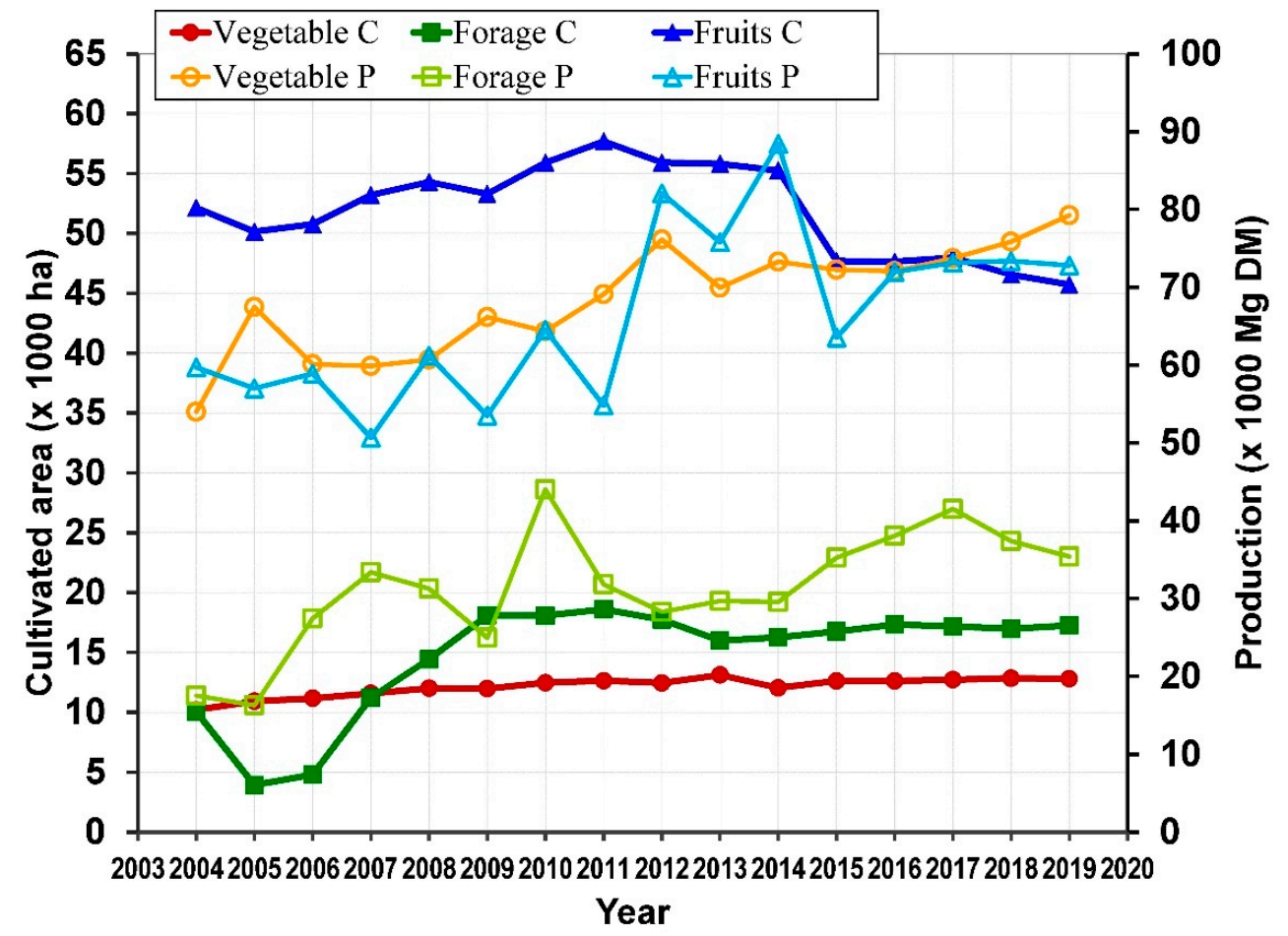

Figure 4. Cultivated (C) area and Production (P) of Opuntia in Mexico (map by the authors with data from SIAP [36]).

Most of the production of vegetable and fruit are rainfed, with approximately $73 \%$ and $98 \%$ of the cultivated area, respectively, whereas forage production of is done by irrigation 
with about $90 \%$ of the cultivated area. The production (in fresh weight) of these cultivated areas is variable, but in general, also shows a growing trend over the years from 2004 to 2019.

The mean water content (\%) for young cladodes for food consumption, cladodes for forage and prickly pear fruit was 92,81 and 86 , respectively $[73,78,79]$. The production $(\mathrm{kg})$ in dry matter (DM) was $5,401,5470$ to $79,272,985$ for vegetable, $16,286,219$ to $44,015,016$ for forage and 50,658,740 to 88,418,540 for fruit (Figure 4). Therefore, the yield ( $\mathrm{kg} \mathrm{ha}^{-1} \mathrm{year}^{-1}$ $\mathrm{DM}$ ) was also variable, this being 5124.7 to 6665.8 for vegetable, 2176.5 to 7889.6 for forage and 1124.5 to $1713.6 \mathrm{~kg}$ for fruit.

The variability of annual mean yield is related to soil conditions, agricultural practices and water inputs. Under rainfed conditions, aboveground dry-weight productivity ( $\mathrm{kg} \mathrm{ha}^{-1}$ year $^{-1} \mathrm{DM}$ ) for Opuntia ficus-indica varies from 3000 to 3170 [8,80,81]. However, under irrigated conditions, the productivity of this specie is between 40,000-50,000. However, lower yields were achieved from 240 to 570 for five cultivars of $O$. ficus-indica under three plant densities and drop irrigation [79]. Productivity is affected by water availability and it is estimated that the yield increases $19.7 \%$ for every $\mathrm{mm}$ of annual rain-fall available. Nevertheless, local and specific field trials are needed to verify the productivity, not only on O. ficus-indica but also for other cultivated species of Opuntia that can be used as biofuel crops.

\section{Potential Agave and Opuntia Species for Fuels Production and Energy}

Sources of carbon mainly depends on the climate and soil conditions of the land [82], therefore, there is a wide condition worldwide. As it was described above, maguey (Agave spp.) and nopal (Opuntia spp.) are two of the most representative plants that are widely distributed in Mexico.

Although bioenergy is the main interest for Agave and Opuntia species as a feedstock, attention has been recently focused on the production of bioethanol, an emerging application is increasing through anaerobic digestion (AD) to produce biogas for electricity generation [11,23,83]. Nevertheless, the thermochemical processing of Agave and Opuntia for thermal and electricity power is still a scarcely studied area [84,85]. In the following paragraphs, some study cases are described as examples of the use of maguey (Agave spp.) and nopal (Opuntia spp.) to obtain sustainable energy. Table 1 shows the chemical composition of biomass for six Agave species and three Opuntia species, in which cellulose, hemicellulose and lignin are the main compounds to produce biofuels.

Table 1. Chemical composition of selected Agave and Opuntia species (\% of total dry weight).

\begin{tabular}{llccc}
\hline Specie & Biomass & Cellulose & Hemicellulose & Lignin \\
\hline \multirow{2}{*}{ A. tequilana } & Bagasse [23,86-89] & $10.6-50.0$ & $10.6-22$ & $6.2-17$ \\
\cline { 2 - 5 } & Leaf fiber [23,90] & $26.1-49.5$ & $15.8-17.8$ & $12.7-17.0$ \\
\cline { 2 - 5 } & Offshoot bagasse [23] & 19.8 & 13.8 & 13.1 \\
\hline A. lechuguilla & Cogollos [91-93] & $14.65-40.98$ & $1.52-12.84$ & $9.07-44.25$ \\
\hline A. americana & Bagasse [94] & 39.4 & & 11.6 \\
\cline { 2 - 5 } & Leaf fiber [90,95] & $5.55-47.2$ & $5.6-22.4$ & $9.1-9.3$ \\
\hline A. salmiana & Leaf fiber [96] & 20.67 & 3.74 & 23.37 \\
\hline A. karwinskii & Bagasse [89] & 30 & 20 & 14 \\
\hline A. deserti & Bagasse [94] & 54.7 & & 17.5 \\
\hline O. ficus-indica & Cladodes [85,97-99] & $3-32.6$ & $6.2-18.5$ & $3.6-16$ \\
\hline O. robusta & Cladodes [99] & 29.1 & 9.9 & 13.1 \\
\hline O. streptacantha & Cladodes [99] & 28.1 & 11.5 & 12.9 \\
\hline
\end{tabular}


The ability to convert CAM crops to both biomethane and volatile fatty acids has received very little research attention. Recently, the biochemical methane potentials of Agave and Opuntia species were studied [100]. The methane yields achieved from the CAM substrates were at least as high as those obtained from maize, which is one of the widely used feedstocks for anaerobic digestion. CAM plants may be viable as bioenergy crops on poor quality soils in areas with low rainfall that are unsuitable for cultivation of food crops. Moreover, the Agave biomass can be used as substrate of low cost to produce a wide number of bioproducts and biofuels in addition to organic acids and enzymes [101].

\subsection{Biofuels, Bioenergy and Byproducts from Agave Species}

Literature review about productivity and bioproducts shows a high potential of some Agave species to compete economically with other bioenergy crops. However, the competition is not the main purpose, since these species should enhance the list of energy crops from which bioenergy could be obtained [41], especially for local and rural sustainable valorization where the capacity to grow with very little rainfall and still reach good amount of biomass is needed. Production of ethanol from Agave must differentiate its use for spirits and others like pharmacy or biofuels. The Tequila industry is a highly profitable one and ethanol production for biofuels must consider low value biomasses, i.e., leaves and Agave bagasse. In fact, considering the average annual production of Agave for Tequila and Mezcal and given methodology [102], dry available biomass of bagasse and leaves of Agave is estimated at about 149,777 ton and 124,814 ton, respectively, from which, theoretically [103], it is possible to obtain 58,762 L of bioethanol, 59,586 L of BTL (Biomass to Liquid)-diesel or 84,299 L of Bio-SNG (Synthetic Natural Gas). A techno-economic study based on process simulation showed that an attractive production cost of ethanol minor to 1.07 USD per gallon may be achieved if the Agave bagasse and hydrolytic enzymes costs are lower than 50 USD per ton and 0.4 USD per gallon, respectively [86]. Nevertheless, Agave residues valorization into ethanol must consider satisfying local needs of fuels in order to get it accessible to the people.

The used of bagasse from Agave tequilana to produce ethanol was described by SaucedoLuna et al. [87], who reported the use of Pichia caribbica UM-5, a native yeast, to ferment sugar liquors from both acid and enzymatic hydrolysis to ethanol, yielding 50 and $87 \%$, respectively. The authors found a conversion of $8.99 \mathrm{~g}$ ethanol $/ 50 \mathrm{~g}\left(0.18 \mathrm{~g}\right.$ ethanol g $^{-1}$ bagasse), corresponding to an overall yield of $56.75 \%$ of theoretical ethanol. Thus, bagasse may be employed as a lignocellulosic raw material for bioethanol production and the bagasse is suitable for further valorization [86]. Agave lechuguilla Torr. is another wild species that grows in the arid and semi-arid zones of Mexico, mainly in the North part of Mexico [104]. This species is becoming of interest for establishing crops to produce fibers and bioethanol $[105,106]$.

The heart with attached leaf of A. lechuguilla (called Cogollos) has been assessed by different strategies to produce ethanol [91-93]. Authors report that pretreatment with diluted sulfuric acid can be a promising option to fractionate biomass. It is also reported that separate hydrolysis and fermentation (SHF) showed the best results compared to simultaneous saccharification and fermentation (SSF) and pre-hydrolysis and simultaneous saccharification and fermentation (PSSF) [91]. In the SHF, ethanol concentration and productivity obtained at $36 \mathrm{~h}$ were $53.7 \mathrm{~g} \mathrm{~L}^{-1}$ and $1.49 \mathrm{~g} \mathrm{~L}^{-1} \mathrm{~h}^{-1}$, respectively, with $25 \%$ $\mathrm{m} / \mathrm{v}$ of solids and an enzyme loading of $25 \mathrm{FPU} \mathrm{g}^{-1}$ glucan (filter paper unit per $\mathrm{g}$ ). Moreover, $87 \%$ of sugar recovery was obtained in raw Agave at $180^{\circ} \mathrm{C}$ and $1.24 \%(\mathrm{~m} / \mathrm{v})$ $\mathrm{H}_{2} \mathrm{SO}_{4}$ and $10 \%$ biomass loading. Then, an enzymatic saccharification yield a sugar solution that was co-fermented by the Escherichia coli MM160, achieving an ethanol yield of 73.3\% in a single step [93].

Agave fourcroydes Lem, best known as Henequen, is usually cultivated in Yucatán, Mexico to produce natural fibers from the leaves, and a juice that contains fructans. Ethanol can be obtained by hydrolyzed fructans to fructose and glucose and metabolized into ethanol by selected yeasts; although yields depend on the variety and age of $A$. fourcroydes; 
for example, cooked piñas of green and white henequen that are 5 years old, produced ethanol yields of 33.36 and $20.73 \mathrm{~mL} \mathrm{~kg}^{-1}$, respectively; whereas with cooked piñas that are 9 years old, the respective ethanol yields were 50.25 and $43.25 \mathrm{~mL} \mathrm{~kg}^{-1}$ [107].

Different Agave species in Mexico are used to provide the carbon source for distilled and non-distilled alcoholic beverage production using the stem of the plant, while the leaves are discarded. Although both hydrolysis processes (thermal acid and enzymatic hydrolysis) obtained similar results, the difference was observed after fermentation. Ethanol yields (\%) were $50 \pm 4$ and $80 \pm 5$ of the theoretical yield, respectively. According to VillegasSilva et al. [82] it is possible to produce ethanol from almost the entire plant (stem and leaves), which is a good option to reduce biomass waste. At the end of 2015 in Morelia City, Michoacan, Mexico, the inauguration of a pilot plant for the ethanol production from juice and biomass of Agave spp. used to obtain tequila and mezcal took place. The main objective is to know the yields of waste to produce second-generation ethanol [108].

Corbin et al. [90] described the bioethanol production from Agave americana and Agave tequilana leaves related to the chemical composition. Agave leaves are rich in soluble sugars and pectin; dry leaf fiber is composed of crystalline cellulose and noncellulosic polysaccharides, and whole leaves were low in lignin. It is important to mention that in tequila making, Agave leaves are discarded as waste. According to the authors, theoretically, up to $4000 \mathrm{~L} \mathrm{ha}^{-1}$ year $^{-1}$ of bioethanol could be produced from juice extracted from waste Agave leaves. However, using Saccharomyces cerevisiae strains to ferment Agave juice, a $66 \%$ yield was obtained. Therefore, Agave could be used as a bioethanol feedstock, adapting fermentation organisms and conditions according to the chemical composition.

Láinez et al. [96] reported an enzymatic saccharification on A. salmiana leaves comparing with Saccharomyces cerevisiae and Kluyveromyces marxianus. The main results showed the efficient hydrolysis of lignocellulosic material from A. salmiana leaves and its successful conversion into ethanol by K. marxianus (fermentative efficiencies of $92.88 \pm 3.24 \%$ vs. S. cerevisiae of $87.63 \pm 2.23 \%$ ).

Sánchez et al. [88] reported an analysis of the tequila residues valorization, considering the residues and wastes in a multi-feedstock Mexican biorefinery for the co-production of second-generation bioethanol and electricity as the best sustainable option for waste valorization. Authors reported one third of the economic cost of biorefinery operation in addition to waste management lower costs. For a $500 \mathrm{Mkg}$ day $^{-1}$ plant, the most sustainable configuration is producing second-generation $(2 \mathrm{G})$ bioethanol with a vinasses treatment plant feeding biogas for electricity coproduction.

In order to produce in Mexico 2G bioethanol, Delfin-Ruíz et al. [89] demonstrated that Agave bagasse is a suitable alternative, obtaining a yield of 0.47 and $0.46 \mathrm{~m} / \mathrm{m}$ in the fermentation step using Agave tequilana Weber var. azul and Agave karwinskii bagasse, respectively. A volumetric productivity of 1.97 and $1.14 \mathrm{~g} \mathrm{~L}^{-1} \mathrm{~h}^{-1}$ and a fermentation efficiency of 93.1 and $90.4 \%$, respectively was also reported.

According to Lu and Wyman [94], A. deserti and cultivated A. americana growths in California and both species are rich in fructans (from 96-314 $\mathrm{g} \mathrm{L}^{-1}$ of equivalent fructose and glucose in their leaf bases). In addition, authors reported that these plants are amenable to fermentation into ethanol and other biofuels considering both structural and watersoluble sugar contents (more than $63 \%$ mass) in addition to the low K-lignin content (12-18\% mass) that suggests low recalcitrance. The recalcitrance of $A$. americana was compared with sorghum, switchgrass and miscanthus. Authors reported that A. americana is more easily hydrolyzed by enzymes with greater sugar yield per unit mass [95] and can produce substantial yields of soluble carbohydrates with lower amount of enzymes with the same polysaccharides depolymerization to fermentable monosaccharides than other lignocellulosic feedstocks.

Agave has been also studied as a solid biofuel (SBF). Considering feasibility studies for process heat, Duran et al. [109] demonstrated that Agave can be used as SBF in a thermal process, indicating that although a biomass boiler is more expensive than a natural gas or fuel oil boiler (8 to 10 times more), the investment is worth due to the cost of fossil fuel. In 
addition, using Agave as an SBF, both $\mathrm{CO}_{2}$ emissions and generation costs of the biofuel were lower than fossil fuel, even considering additional biomass like woodchip. Another advantage is that leaves from Agave are waste that can be valorized as SBF, reducing the amount of woodchips, with a possible corresponding decrease in heat generation cost.

In order to assess the structural and chemical recalcitrance of different types of biomass, including bagasse (AB) from A. salmiana gentry, FTIR spectroscopy and TGA were used [110]. A partial decomposition of polysaccharide and the thermal recalcitrance of $\mathrm{AB}$ was reported and this behavior is controlled by the chemical linking between polysaccharides and lignin of $\mathrm{AB}$.

The evaluation of $\mathrm{AB}$ pretreated with steam explosion and enzymatic hydrolysis for biomethane production was described by Duran-Cruz et al. [111] using severity factors (SF) ranged from 1.65 to 2.89; hydrolysis with enzyme loads of Cellic CTec2 ranged from 0.12 to $3.6 \mathrm{mg}$ protein $\mathrm{g}^{-1} \mathrm{AB}$. The contribution of pretreatment to the global TC yield ranged from 13 to $34 \%$ for the different systems evaluated and the best SF was of 2.41 . The BMP value was 40\% higher than the BMP reached without enzymatic hydrolysis. In all cases, pretreatment resulted in higher TC yields after enzymatic hydrolysis, indicating the relevance of this first step for the use of $\mathrm{AB}$ for biofuel production. Additionally, such pretreatment conditions correspond to less severe conditions, implicating a reduction in the energy and time invested in this process and directly affecting the costs of biogas production. Likewise, the use of hydrolytic enzymes contributes with a cleaner process and reduces the use of harmful chemicals.

\subsection{Biogas and Energy from the Opuntia Species}

It is well known that the content of digestible carbohydrates, lipids and proteins, in addition to the content of more resistant cellulose, hemicellulose and lignin impacts the production of biogas. One of the first works describing the conditions to obtain biogas from Opuntia is the one reported by Contreras and Toha [112]. According to them, homogenized cladodes of the cactus Opuntia cacti (ficus-indica) maintained in closed vials at atmospheric pressure, spontaneously emit a gas that is $17 \%$ hydrogen. This early gas emission produced in only a few hours of incubation is enhanced by the addition of a small amount (1\% $v / v$ ) of digested sludge, and attains its maximum at $\mathrm{pH} 6$ and at $35-40{ }^{\circ} \mathrm{C}$. On the other hand, after days of incubation with digested sludge a different larger gas production was induced $\left(\approx 500 \mathrm{~mL} \mathrm{~g}^{-1}\right.$, dry weight) containing $60 \%$ methane and very little hydrogen. After about 26 days of incubation the biomass was reduced to $10 \%$ of the original mass. In both processes higher yields of gas production were obtained by the incubation of the pith fraction of the cladodes. Krümpel et al. [97] reported that 20,000 plants ha ${ }^{-1}$ of Opuntia ficus-indica (L) Mill was able to generate a methane yield of $1860 \mathrm{~m}^{3}$ from 1 ha on a marginal land. In line with this, pretreated napier grass with cow farm slurry allowed the production of biogas with $66 \%$ methane content [113].

Retamal et al. [114] reported the ethanol production from fruits and cladodes of prickly pear cactus, using different yeast strains of the genus Saccharomyces. The best results after both types of hydrolysis were obtained with fresh or dried cladodes without fruits. The enzymatic method gave the highest sugar yield, but the production of ethanol was similar to the one obtained by hydrolysis of fresh cladodes with acid, and only slightly higher with dried cladodes. Authors highlighted the utilization of inexpensive lignocellulosic biomass for the production of ethanol from prickly pear cultivation in arid, semi-arid and irrigated regions. Therefore, the cladodes of $O$. ficus-indica are suitable biomass for a second-generation feedstock and there is not any competition for prime agricultural land, food production or significantly replacing natural vegetation.

Cactus is an interesting option to be used as energetic resource since it is established and developed in marginal areas. In addition, nopal can be used to recover poor and eroded soils. The bioenergy from cactus biomass is considered almost never-ending, clean and can be used in a self-maintained manner, since they have the advantage of being used in the same place or nearby where they are produced [83]. Ortiz-Laurel and Rössel-Kipping [115] 
described the balance of energy for biogas generation from cactus prickly, which produces large quantities of biomass (11.3\% dry matter). They found that it is difficult to use prickly cactus as natural material for biorefinery since quality of cactus biomass as large number of cladodes are discarded because of its unavailability as livestock fresh fodder and those still act attached to the plant get mature and eventually get old. In order to reduce energy consumption, they suggest a short distance transportation of raw material and undertake a basic process-low investment and supplying small quantities of energy. Cactus shows on average one of the highest methane production to biomass ratios $(57.12 \%)$; therefore, it is a sustainable source for obtaining biogas.

Texco-López et al. [98] studied the effect of hydrothermal pretreating (high pressure) and enzymatic hydrolysis of cladodes of Opuntia ficus-indica on sugar release and their potential use in bioethanol production. They achieved a final hydrolysis of $70.4 \%$ of the nopal cladodes (combination of thermal pretreatment and enzymatic hydrolysis) and bioethanol production of $6.6 \mathrm{~g} \mathrm{~L}^{-1}$. In addition, a significant time saving by applying a hydrothermal pretreatment compared to a conventional pretreatment (carried out in autoclaves) was reported.

The characterization of Opuntia ficus-indica using FTIR spectroscopy showed a high amount of cellulose (32.6\%) and hemicelluloses (9.8\%). The syringyl:guaiacyl ratio was 1.59 to 2.12 , due to the presence of $60 \%$ of syringyl in the lignin fraction. Percentages higher than $60 \%$ of crystalline cellulose were reported. Therefore, the chemical composition of lignin and cellulose as well as lignocellulosic percentages allow Opuntia species to be suitable for cellulose nanofibers and biofuels production [99].

A recent work reported the value of tropical fruit byproducts in a bio-refinery scheme. Particular attention was given to bioactive compounds (phenolics and carotenoids) [43].

The development of production systems with low energy requirements, such as the nopal, contribute to sustainable development, promoting an increase in the quality of life in marginal areas [73]. The biogas obtained from the nopal can be used as an alternative fuel in those marginal communities in countries where the power supply is deficient or there is not access to conventional sources [116]. Panizio et al. [117] reported that Opuntia sp could be applied as a novel co-substrate in wastewater digestion systems that contain high levels of nitrogen compounds, due to the co-digestion of slaughterhouse wastewater with Opuntia ficus-indica residues that enhanced the production of biogas.

\section{Challenges and Perspectives}

Agave and Opuntia species are very valuable in Mexico for food, cattle feed and spirit production as stated above. Nevertheless, valuable biomass is left behind in the land as fertilizers without any other valorization. We consider that a fraction of such biomass residues may be valorize into biofuels and bioproducts for an enhanced added value to the rural communities that cultivate these plants. Such valorization may permit the local production of biofuels like ethanol, biogas and methane, helping to the accessibility of energy to the rural people, instead of using fossil fuels like liquified petroleum gas (LPG) or natural gas.

Further valorization of such residues may allow the productions of fructans as inulin from Agave and pectin from Opuntia. Then, we need to undertake sustainable production projects all along with rural communities working with metepantle in order to maximize the use of biomass and heading to a circular bioeconomy.

It has been previously described that Agave and Opuntia spp. are currently receiving attention as potential bioproducts and bioenergy feedstocks. However, there are still some characteristics that limit the ability of both species to fully compete economically and environmentally with other bioenergy crops in the production of biofuels, bioenergy and byproducts. First, some species of Agave are used for the tequila industry and currently continues without further vision. Even more, although theoretical maximum ethanol yield is much better for Agave (twofold) than non-CAM biofuel crops, switchgrass and poplar, the authors think that a change in paradigm is necessary for biomass and biowaste exploita- 
tion to really valorize their potential. Second, although the scope of ethanol production from Opuntia spp. has historically been far more limited than from Agave, few attempts to convert Opuntia cladodes or fruit to ethanol have been reported (e.g., Sánchez et al. [88]). Third, environmental impacts, addressed through life cycle assessment, concluded that both energy outputs and greenhouse emissions are greater in an Agave bioenergy production system than in corn or switchgrass bioenergy production systems [23]. Further quantitative studies are needed to revised inventory and inferences to be made in addition to allocation issues. It is worth saying that Agave is far more water-use efficient than these traditional crops [21]. Finally, there are substantial costs that need to be addressed before biomass and waste from Agave can be used to produce energy, mainly due to costs associated with the manual labor for its production in addition to pretreatment that account for cost. As mentioned before, both species theoretically require less-aggressive pretreatment steps according to their chemical composition. However, deconstructive pretreatments of raw lignocellulosic biomass account for most of the costs associated with lignocellulosic biofuel production.

Now, energy policy and programs must be oriented in order to facilitate the access of energy and productive processes to such rural communities, with social, environmental and health welfare. In Mexico, the lack of a long-term policy, bioenergy mandate or the subsidies to fossil fuels and electricity have complicated the appearance of a biomass and bioenergy market. Still, this lack of policy may threaten in some cases the environment, household income and regional production of certain products due to deforestation [118]. Hence, decision makers must intensify the revision of the policies, regulations and standards concerning the use of biomass and bioenergy since country partners like USA, Brazil and Canada are more advanced on this subject [119]. Indeed, appropriate policies must promote an adequate use of water and land, as well as its management, a sustainable market for biomass and bioenergy, the creation of employment, the implementation of specialized courses and education for the population, the diminution of greenhouse emissions, as well as the definition of specifications and standards for biomass and bioenergy [120-122]. Intensive cultivation and valorization of Agave and Opuntia also have opportunities to valorize their residues into energy and bioproducts, but it usually depends on the price of fossil fuels or the main markets that such industries engaged and disregard about new approaches. Here, this is an opportunity to create new value chains for a suitable bioeconomy.

The science and technology to valorize Agave and Opuntia residues already exists or may be adaptable, but suitable government programs, interest of stakeholders, addressing a circular economy perspective and a lack of information in rural communities about the potential of the biomass are all challenges that must be addressed with a pentahelix approach.

Author Contributions: Conceptualization, J.A. and M.A.A.-A.; methodology, J.A.H.-S.; formal analysis, J.A.H.-S., M.A.A.-A. and J.A.; investigation, M.A.A.-A., J.A. and J.A.H.-S.; writing-original draft preparation, M.A.A.-A. writing-review and editing, M.A.A.-A., J.A.H.-S. and J.A.; supervision, M.A.A.-A.; project administration, J.A.; funding acquisition, not applicable. All authors have read and agreed to the published version of the manuscript.

Funding: This research did not receive any specific grant from funding agencies in the public, commercial, or not-for-profit sectors.

Institutional Review Board Statement: Not Applicable.

Informed Consent Statement: Not Applicable.

Data Availability Statement: Further information required to review the work reported in the manuscript is available will be provided previous request to the corresponding author.

Acknowledgments: Authors thank the support of IMP and INIFAP along COVID-19 pandemic.

Conflicts of Interest: The authors declare no conflict of interest. 


\section{References}

1. Bhuyar, P.; Sundararaju, S.; Rahim, M.H.A.; Maniam, G.P.; Govindan, N. Enhanced productivity of lipid extraction by urea stress conditions on marine microalgae Coelastrum sp. for improved biodiesel production. Bioresour. Technol. Rep. 2021, 15, 100696. [CrossRef]

2. Jayakumar, S.; Bhuyar, P.; Pugazhendhi, A.; Rahim, M.H.A.; Maniam, G.P.; Govindan, N. Effects of light intensity and nutrients on the lipid content of marine microalga (diatom) Amphiprora sp. for promising biodiesel production. Sci. Total Environ. 2021, 768, 145471. [CrossRef] [PubMed]

3. Bhuyar, P.; Yusoff, M.M.; Rahim, M.H.A.; Sundararaju, S.; Maniam, G.P.; Govindan, N. Govindan Effect of plant hormones on the production of biomass and lipid extraction for biodiesel production from microalgae Chlorella sp. J. Microbiol. Biotechnol. Food Sci. 2020, 9, 671-674. [CrossRef]

4. Whangchai, K.; Souvannasouk, V.; Bhuyar, P.; Ramaraj, R.; Unpaprom, Y. Biomass generation and biodiesel production from macroalgae grown in the irrigation canal wastewater. Water Sci. Technol. 2021, 2021195. [CrossRef]

5. Iizumi, T.; Ramankutty, N. How do weather and climate influence cropping area and intensity? Glob. Food Secur. 2015, 4, 46-50. [CrossRef]

6. Cohn, A.S.; VanWey, L.K.; Spera, S.; Mustard, L.K.V.S.A.S.J.F. Cropping frequency and area response to climate variability can exceed yield response. Nat. Clim. Chang. 2016, 6, 601-604. [CrossRef]

7. Campbell, J.E.; Lobell, D.B.; Genova, R.C.; Field, C.B. The Global Potential of Bioenergy on Abandoned Agriculture Lands. Environ. Sci. Technol. 2008, 42, 5791-5794. [CrossRef]

8. Cushman, J.C.; Davis, S.C.; Yang, X.; Borland, A.M. Development and use of bioenergy feedstocks for semi-arid and arid lands. J. Exp. Bot. 2015, 66, 4177-4193. [CrossRef] [PubMed]

9. Cuevas, E.; Blancas, J.; Caballero, J.; Hinojoza-Díaz, I.A.; Martínez-Ballesté, A. Agricultural management and local knowledge: Key factors for the conservation of socio-ecosystems in the face of the pollinator world crisis. Bot. Sci. 2021, 99, 305-320. [CrossRef]

10. Cabrera-Toledo, D.; Vargas-Ponce, O.; Ascencio-Ramírez, S.; Valadez-Sandoval, L.M.; Pérez-Alquicira, J.; Morales-Saavedra, J.; Huerta-Galván, O.F. Morphological and Genetic Variation in Monocultures, Forestry Systems and Wild Populations of Agave maximiliana of Western Mexico: Implications for Its Conservation. Front. Plant Sci. 2020, 11, 817. [CrossRef]

11. Mason, P.M.; Glover, K.; Smith, J.A.C.; Willis, K.J.; Woods, J.; Thompson, I.P. The potential of CAM crops as a globally significant bioenergy resource: Moving from 'fuel or food' to 'fuel and more food'. Energy Environ. Sci. 2015, 8, 2320-2329. [CrossRef]

12. Owen, N.A.; Fahy, K.; Griffiths, H. Crassulacean acid metabolism (CAM) offers sustainable bioenergy production and resilience to climate change. GCB Bioenergy 2015, 8, 737-749. [CrossRef]

13. Borland, A.M.; Griffiths, H.; Hartwell, J.; Smith, J.A.C. Exploiting the potential of plants with crassulacean acid metabolism for bioenergy production on marginal lands. J. Exp. Bot. 2009, 60, 2879-2896. [CrossRef] [PubMed]

14. Borland, A.; Hartwell, J.; Weston, D.; Schlauch, K.A.; Tschaplinski, T.; Tuskan, G.; Yang, X.; Cushman, J.C. Engineering crassulacean acid metabolism to improve water-use efficiency. Trends Plant Sci. 2014, 19, 327-338. [CrossRef]

15. Cai, X.; Zhang, X.; Wang, D. Land Availability for Biofuel Production. Environ. Sci. Technol. 2011, 45, 334-339. [CrossRef]

16. Food and Agricultural Organization of the United Nations (FAO). Arid Zone Forestry: A Guide for Field Technicians, FAO Conservation Guide, 20; FAO: Rome, Italy, 1989.

17. United Nations Convention to Combat Desertification (UNCCD), Desertification: A Visual Synthesis; United Nations Convention to Combat Desertification Secretariat: Bonn, Germany, 2011.

18. Galán-Reséndiz, M. Contribución al Entendimiento del Sistema Agroforestal Con Metepantle en Tepetlaoxtoc, México. Master's in Sciences Thesis. Available online: http:/ / repositorio.chapingo.edu.mx:8080/bitstream/handle/20.500.12098/544/mcads-grm18.pdf? sequence=2\&isAllowed $=y$ (accessed on 7 September 2021).

19. Mielenz, J.R.; Rodriguez, M., Jr.; Thompson, O.A.; Yang, X.; Yin, H. Development of Agave as a dedicated biomass source: Production of biofuels from whole plants. Biotechnol. Biofuels 2015, 8, 1-13. [CrossRef] [PubMed]

20. Yang, L.; Lu, M.; Carl, S.; Mayer, J.A.; Cushman, J.C.; Tian, E.; Lin, H. Biomass characterization of Agave and Opuntia as potential biofuel feedstocks. Biomass Bioenergy 2015, 76, 43-53. [CrossRef]

21. Davis, S.C.; Kuzmick, E.R.; Niechayev, N.; Hunsaker, D.J. Productivity and water use efficiency of Agave americana in the first field trial as bioenergy feedstock on arid lands. GCB Bioenergy 2016, 9, 314-325. [CrossRef]

22. Niechayev, N.A.; Jones, A.M.; Rosenthal, M.D.; Davis, S.C. A model of environmental limitations on production of Agave americana L. grown as a biofuel crop in semi-arid regions. J. Exp. Bot. 2019, 70, 6549-6559. [CrossRef] [PubMed]

23. Yan, X.; Corbin, K.R.; Burton, R.A.; Tan, D.K. Agave: A promising feedstock for biofuels in the water-energy-food-environment (WEFE) nexus. J. Clean. Prod. 2020, 261, 121283. [CrossRef]

24. Hopkins, W.G.; Hüner, N.P.A. Introduction to Plant Physiology; John Wiley \& Sons, Inc.: Hoboken, NJ, USA, 2009.

25. Nobel, P.S. Physicochemical and Environmental Plant Physiology, 4th ed.; Elsevier Academic Press: Oxford, UK, 2009.

26. García-Mendoza, A.J. Distribution of the genus Agave (Agavaceae) and its endemic species in Mexico. Cactus Succul. J. 2002, 74, 177-187.

27. García-Mendoza, A.J. Los Agaves de México. Ciencias 2007, 87, 14-23.

28. Esparza, S.S. Distribución Geográfica del Género Opuntia (Cactaceae) en México. Master's Thesis, Universidad Autónoma de San Luis Potosí, San Luis Potosí, Mexico, 2010. 
29. Díaz-Padilla, G.; Sánchez-Cohen, I.; Guajardo-Panes, R.A.; Del Ángel-Pérez, A.L.; Ruíz-Corral, A.; Medina-García, G.; IbarraCastillo, D. Mapeo del índice de aridez y su distribución poblacional en méxico. Rev. Chapingo Ser. Cienc. For. Ambient. 2011, XVII, 267-275. [CrossRef]

30. Liu, D.; Palla, K.J.; Hu, R.; Moseley, R.; Mendoza, C.; Chen, M.; Abraham, P.E.; Labbé, J.L.; Kalluri, U.C.; Tschaplinski, T.; et al. Perspectives on the basic and applied aspects of crassulacean acid metabolism (CAM) research. Plant Sci. 2018, 274, 394-401. [CrossRef]

31. Davis, S.C.; Simpson, J.; Gil-Vega, K.D.C.; A Niechayev, N.; Van Tongerlo, E.; Castano, N.H.; Dever, L.V.; Búrquez, A. Undervalued potential of crassulacean acid metabolism for current and future agricultural production. J. Exp. Bot. 2019, 70, 6521-6537. [CrossRef] [PubMed]

32. Davis, S.C.; Dohleman, F.G.; Long, S. The global potential for Agave as a biofuel feedstock. GCB Bioenergy 2010, 3, 68-78. [CrossRef]

33. Chambers, D.; Holtum, J.A.M. Feasibility of Agave as a Feedstock for Biofuel Production in Australia; Publication No. 10/104; Rural Industries Research and Development Corporation: Barton, Australia, 2010; p. 74.

34. Owen, N.A.; Griffiths, H. Marginal land bioethanol yield potential of four crassulacean acid metabolism candidates (Agave fourcroydes, Agave salmiana, Agave tequilana and Opuntia ficus-indica) in Australia. GCB Bioenergy 2014, 6, 687-703. [CrossRef]

35. Davis, S.C.; Abatzoglou, J.T.; LeBauer, D.S. Expanded Potential Growing Region and Yield Increase for Agave americana with Future Climate. Agronomy 2021, 11, 2109. [CrossRef]

36. Servicio de Información Agroalimentaria y Pesquera (SIAP). Producción Agropecuaria y Pesquera, Producción anual. Estadística de Producción Agrícola, Datos Abiertos, Secretaría de Agricultura, Ganadería, Desarrollo Rural, Pesca y Alimentación. 2020. Available online: http://infosiap.siap.gob.mx/gobmx/datosAbiertos_a.php (accessed on 20 May 2021).

37. Davis, S.C.; Griffiths, H.; Holtum, J.; Saavedra, A.L.; Long, S.P. The Evaluation of Feedstocks in GCBB Continues with a Special Issue on Agave for Bioenergy. GCB Bioenergy 2011, 3, 1-3. [CrossRef]

38. Davis, S.C.; Lebauer, D.S.; Long, S.P. Light to liquid fuel: Theoretical and realized energy conversion efficiency of plants using Crassulacean Acid Metabolism (CAM) in arid conditions. J. Exp. Bot. 2014, 65, 3471-3478. [CrossRef] [PubMed]

39. Holtum, J.A.M.; Chambers, D.; Morgan, T.; Tan, D.K.Y. Agave as a biofuel feedstock in Australia. GCB Bioenergy 2010,3 , 58-67. [CrossRef]

40. Núñez, H.M.; Rodríguez, L.F.; Khanna, M. Agave for tequila and biofuels: An economic assessment and potential opportunities. GCB Bioenergy 2010, 3, 43-57. [CrossRef]

41. Escamilla-Treviño, L.L. Potential of Plants from the Genus Agave as Bioenergy Crops. BioEnergy Res. 2011, 5, 1-9. [CrossRef]

42. Nobel, P.S. Environmental Biology of Agaves and Cacti; Cambridge University Press: Cambridge, UK, 1988.

43. Villacís-Chiriboga, J.; Elst, K.; Van Camp, J.; Vera, E.; Ruales, J. Valorization of byproducts from tropical fruits: Extraction methodologies, applications, environmental, and economic assessment: A review (Part 1: General overview of the byproducts, traditional biorefinery practices, and possible applications). Compr. Rev. Food Sci. Food Saf. 2020, 19, 405-447. [CrossRef] [PubMed]

44. García-Mendoza, A.J. Flora del Valle de Tehuacán-Cuicatlán; Instituto de Biología, Universidad Nacional Autónoma de México: Mexico City, Mexico, 2011; p. 88.

45. Gentry, H.S. Agaves of Continental North America; University of Arizona Press: Tucson, AZ, USA, 1982.

46. Colunga-García, M.; Zizumbo-Villarreal, D.; Martínez-Torres, J. Tradiciones en el aprovechamiento de los Agaves mexicanos: Una aportación a la protección legal y conservación biológica y cultural. In En lo Ancestral Hay Futuro: Del Tequila, los Mezcales y Otros Agaves; Colunga-García, M.P., Eguiarte, S.A.L., Zizumbo-Villarreal, D., Eds.; Centro de Investigación Científica de Yucatán, A.C.: Mérida, Yucatán, Mexico, 2007.

47. Comisión Nacional para el Conocimiento y Uso de la Biodiversidad (CONABIO), Red Mundial de Información sobre Biodiversidad (REMIB). 2016. Available online: http:/ / www.conabio.gob.mx/remib/doctos/remibnodosdb.html? (accessed on 19 April 2021).

48. Diario Oficial de la Federación (DOF). NORMA Oficial Mexicana NOM-006-SCFI-2012, Bebidas alcohólicas-TequilaEspecificaciones, 13 December 2012. Diario Oficial de la Federación 2012, 912, 5-25.

49. Sistema Nacional de Investigación y Transferencia Tecnológica para el Desarrollo Rural Sustentable (SNITT). Agenda Nacional de Investigación, Innovación y Transferencia de Tecnología, Agrícola 2016-2022; SNITT- SAGARPA: Ciudad de México, Mexico, 2016.

50. Diario Oficial de la Federación (DOF). Resolución por la que se modifica la declaración general de protección de la denominación de origen Mezcal. Diario Oficial Federación 2001, 578, 72-86.

51. García-Mendoza, A.J. Sistemática y distribución actual de los Agave spp. mezcaleros; Universidad Nacional Autónoma de México: Instituto de Biología, Bases de datos SNIB-CONABIO, proyecto V029: Mexico, 2003. Available online: http:/ /ipttest.conabio.gob. $\mathrm{mx}$ /iptconabiotest/resource?r=SNIB-V029\&request_locale=ru (accessed on 5 March 2019).

52. Colunga-García Marín, P.; Zizumbo-Villarreal, D. El tequila y otros mezcales del centro-occidente de México: Domesticación, diversidad y conservación de germoplasma. In En Lo Ancestral Hay Futuro: Del Tequila, Los Mezcales Y Otros Agaves; ColungaGarcía Colunga-García Marín, P., Larqué, S.A., Eguiarte, L.E., Zizumbo-Villarreal, D., Eds.; Mérida, YucatánMexico: Mérida, Yucatán, Mexico, 2007.

53. Diario Oficial de la Federación (DOF). Declaración General de Protección de la Denominación de Origen Raicilla, 28 June 2019. Diario Oficial Federación 2019, 789, 93-100.

54. Gardea, A.A.; Findley, L.T.; Orozco-Avitia, J.A.; Bañuelos, N.; Esqueda, M.; Huxman, T.H. Bacanora and Sotol: So Far, So Close. Estud. Soc. 2012, 2, 153-168. 
55. Reynoso-Santos, R.; García-Mendoza, A.J.; López-Báez, W.; López-Luna, A.; Cadena-Iñiguez, P.; Pérez-Farrera, M.A.; DomínguezGutiérrez, M.H. Identificación taxonómica de Agaves (Agave spp.) utilizados para la elaboración del licor comiteco en Chiapas, México. Agroproductividad 2012, 5, 9-17.

56. Nobel, P. Crop ecosystem responses of climatic change. Crassulacean acid metabolism crops. In Climate Change and Global Crop Productivity; Reddy, K., Hodges, H., Eds.; CAB International: Wallingford, UK, 2020; pp. 315-331.

57. Subedi, R.; Akbar, D.; Ashwath, N.; Rolfe, J.; Rahman, A. Assessing the Viability of Growing Agave tequilana as a Biofuel Feedstock in Queensland, Australia. Int. J. Energy Econ. Policy 2017, 7, 172-180.

58. Iñiguez-Covarrubias, G.; Díaz-Teres, R.; Sanjuan-Dueñas, R.; Anzaldo-Hernández, J.; Rowell, R.M. Utilization of by-products from the tequila industry. Part 2: Potential value of Agave tequilana Weber azul leaves. Bioresour. Technol. 2001, 77, 101-108. [CrossRef]

59. Montañez, J.L.; Victoria, J.C.; Flores, R.; Vivar, M.Á. Fermentación de los fructanos del Agave tequilana Weber azul por Zymomonas mobilis y Saccharomyces cerevisiae en la producción de bioetanol. Información Tecnol. 2011, 22, 3-14. [CrossRef]

60. Nobel, P.S. Achievable productivities of certain CAM plants: Basis for high values compared with C3 and C4 plants. New Phytologist 1991, 119, 183-205. [CrossRef] [PubMed]

61. Zúñiga-Estrada, L.; Rosales, R.E.; Yáñez-Morales, M.J.; Jacques-Hernández, C. Characteristics and productivity of a CAM plant, Agave tequilana developed with fertigation in Tamaulipas, Mexico. Rev. Mexicana Cienc. Agric. 2018, 9, 553-564. [CrossRef]

62. Garcia-Moya, E.; Romero-Manzanares, A.; Nobel, P.S. Highlights for Agave Productivity. GCB Bioenergy 2010, 3, 4-14. [CrossRef]

63. Ruiz-Corral, J.A.; Pimienta-Barrios, E.; Zañudo-Hernández, J. Optimal and marginal thermal regions for the cultivation of Agave tequilana on the Jalisco state. Agrociencia 2002, 36, 41-53.

64. Mariles, F.V. Relación entre las clases de tierra y la calidad de Agave angustifolia Haw. En la Soledad Salinas, Quiatoni, Oaxaca, Mexico. Master's Thesis, Colegio de Postgraduados, Montecillo, Texcoco, Mexico, 2014.

65. Stewart, J.R. Agave as a model CAM crop system for a warming and drying world. Front. Plant Sci. 2015, 6, 684. [CrossRef] [PubMed]

66. Bouaziz, M.A.; Rassaoui, R.; Besbes, S. Chemical Composition, Functional Properties, and Effect of Inulin from Tunisian Agave americana L. Leaves on Textural Qualities of Pectin Gel. J. Chem. 2014, 2014, 1-11. [CrossRef]

67. SAGARPA. Agave tequilero y mezcalero mexicano. In Planeación Agrícola Nacional 2017-2030; SAGARPA: Ciudad de México, Mexico, 2017; p. 15.

68. Diario Oficial de la Federación (DOF). Lineamientos de Operación del Programa Sembrando Vida, 24 January 2019. Diario Oficial Federación 2019, 764, 2-32.

69. Chávez-Moreno, C.K.; Tecante, A.; Casas, A. The Opuntia (Cactaceae) and Dactylopius (Hemiptera: Dactylopiidae) in Mexico: A historical perspective of use, interaction and distribution. Biodivers. Conserv. 2009, 18, 3337-3355. [CrossRef]

70. Griffith, M.P.; Porter, J.M. Phylogeny of Opuntioideae (Cactaceae). Int. J. Plant Sci. 2009, 170, 107-116. [CrossRef]

71. Hernandez, H.M.; Godinez, H. Contribución al conocimiento de las cactáceas mexicanas amenazada. Acta Bot. Mex. 1994, 26, 33. [CrossRef]

72. Reyes-Agüero, J.A.; Aguirre Rivera, J.R.; Flores, J.L. Variación morfológica de Opuntia (cactaceae) en relación con su domesticación en la altiplanicie meridional de México. Interciencia 2005, 30, 476-484.

73. Food and Agricultural Organisation of the United Nations (FAO). Agro-Industrial Utilization of Cactus Pear; FAO: Rome, Italy, 2013.

74. National Institute of Statistics, Geography and Informatics (INEGI), Land use and vegetation, series VI. 2017. Available online: http:/ / www.inegi.org.mx/geo/contenidos/recnat/usosuelo/Default.aspx (accessed on 23 August 2021).

75. Scheinvar, L.; Gallegos, C.; Olalde, G.; Sánchez, V.; Linaje, M. Estado del Conocimiento de las Especies de Nopal (Opuntia spp.) Productoras de Xoconostles Silvestres y Cultivadas (Informe Final); CONABIO: Mexico City, Mexico, 2011.

76. Soberon, J.; Golubov, J.; Sarukhan, J. The Importance of Opuntia in Mexico and Routes of Invasion and Impact of Cactoblastis cactorum (Lepidoptera: Pyralidae). Fla. Èntomol. 2001, 84, 486. [CrossRef]

77. Flores, H.A.; Castillo, I.O.; Martínez, J.M.M.; Rivera, M.G.; Hernández, J.G. Productividad del nopal para verdura (Opuntia spp.) bajo riego por goteo subterráneo en la Comarca Lagunera. Rev. Chapingo Ser. Zonas Áridas (RChSZA) 2004, 3, 99-104.

78. López-García, J.J.; Fuentes-Rodríguez, J.M.; Rodríguez, R.A. Production and use of Opuntia as forage in Northern Mexico. In Cactus (Opuntia spp.) as Forage; Mondragon-Jacobo, C., Pérez-González, S., Eds.; FAO: Rome, Italy, 2001; pp. $29-38$.

79. Ruiz-Espinoza, F.H.; Alvarado-Mendoza, J.F.; Murillo-Amador, B.; García-Hernández, J.L.; Pargas-Lara, R.; Duarte-Osuna, J.D.; Beltrán-Morales, F.A.; Fenech-Larios, L. Yield and Growth of Green Cladodes of Prickly Pear (Opuntia ficus-indica) Cultivars under Different Plant Densities. J. Prof. Assoc. Cactus Dev. 2008, 10, $22-35$.

80. Nobel, P.S. Environmental productivity indices and productivity for Opuntia ficus-indica under current and elevated atmospheric CO2 levels*. Plant Cell Environ. 1991, 14, 637-646. [CrossRef]

81. Nobel, P.S.; Garcia-Moya, E.; Quero, E. High annual productivity of certain agaves and cacti under cultivation. Plant Cell Environ. 1992, 15, 329-335. [CrossRef]

82. Villegas-Silva, P.A.; Toledano-Thompson, T.; Canto-Canché, B.B.; Larqué-Saavedra, A.; Barahona-Pérez, L.F. Hydrolysis of Agave fourcroydes Lemaire (henequen) leaf juice and fermentation with Kluyveromyces marxianus for ethanol production. BMC Biotechnol. 2014, 14, 14. [CrossRef]

83. Méndez-Gallegos, S.J.; Rössel, D.; Amante-Orozco, A.; Gómez-González, A.; García-Herrera, J.E. El nopal en la producción de biocombustibles. VIII Simposium “Producción y aprovechamiento del nopal”. Rev. Salud Pública Y Nutr. 2010, 5, 70-84. 
84. Melane, M.; Ham, C.; Meincken, M. Characteristics of selected non-woody invasive alien plants in South Africa and an evaluation of their potential for electricity generation. J. Energy South. Afr. 2017, 28, 92. [CrossRef]

85. Quiroz, M.; Varnero, M.T.; Cuevas, J.G.; Sierra, H. Cactus pear (Opuntia ficus-indica) in areas with limited rainfall for the production of biogas and biofertilizer. J. Clean. Prod. 2021, 289, 125839. [CrossRef]

86. Barrera, I.; Allieri, M.A.; Estupiñan, L.; Martínez, T.; Aburto, J. Technical and economical evaluation of bioethanol production from lignocellulosic residues in Mexico: Case of sugarcane and blue agave bagasses. Chem. Eng. Res. Des. 2016, 107, 91-101. [CrossRef]

87. Saucedo-Luna, J.; Castro-Montoya, A.J.; Martinez-Pacheco, M.M.; Sosa-Aguirre, C.R.; Campos-Garcia, J. Efficient chemical and enzymatic saccharification of the lignocellulosic residue from Agave tequilana bagasse to produce ethanol by Pichia caribbica. J. Ind. Microbiol. Biotechnol. 2011, 38, 725-732. [CrossRef] [PubMed]

88. Sanchez, A.; Dueñas, P.; Hernandez-Sanchez, P.; Guadalajara, Y. The Role of Sustainability Analysis in the Revalorization of Tequila Residues and Wastes Using Biorefineries. Waste Biomass Valorization 2020, 11, 701-713. [CrossRef]

89. Delfin-Ruíz, M.E.; Calderón-Santoyo, M.; Ragazzo-Sánchez, J.A.; Gómez-Rodríguez, J.; Aguilar-Uscanga, M.G. Ethanol Production from Enzymatic Hydrolysates Optimized of Agave tequilana Weber var. azul and Agave karwinskii bagasses. BioEnergy Res. 2021, 14, 785-798. [CrossRef]

90. Corbin, K.R.; Byrt, C.; Bauer, S.; DeBolt, S.; Chambers, D.; Holtum, J.A.M.; Karem, G.; Henderson, M.; Lahnstein, J.; Beahan, C.T.; et al. Prospecting for Energy-Rich Renewable Raw Materials: Agave Leaf Case Study. PLoS ONE 2015, 10, e0135382. [CrossRef]

91. Morales-Martínez, T.K.; Díaz-Blanco, D.I.; Rodríguez-de la Garza, J.A.; Morlett-Chávez, J.; Castro-Montoya, A.J.; Quintero, J.; Aroca, G.; Rios-González, L.J. Assessment of different saccharification and fermentation configurations for ethanol production from Agave lechuguilla. Bioresources 2017, 12, 8093-8105. [CrossRef]

92. Ortíz-Méndez, O.H.; Morales-Martínez, T.K.; Rios-González, L.J.; Rodríguez-de la Garza, J.A.; Quintero, J.; Aroca, G. Bioethanol production from Agave lechuguilla biomass pretreated by autohydrolysis, Rev. Mex. De Ing. Quimica 2019, 16, 467-476. [CrossRef]

93. Díaz-Blanco, D.I.; de La Cruz, J.R.; López-Linares, J.C.; Morales-Martínez, T.K.; Ruiz, E.; Rios-González, L.J.; Romero, I.; Castro, E. Optimization of dilute acid pretreatment of Agave lechuguilla and ethanol production by co-fermentation with Escherichia coli MM160. Ind. Crop. Prod. 2018, 114, 154-163. [CrossRef]

94. Lu, M.L.; Wyman, C.E. Elucidation of native California Agave americana and Agave deserti biofuel potential: Compositional analysis. PLoS ONE 2021, 16, e0252201. [CrossRef]

95. Jones, A.M.; Zhou, Y.; Held, M.A.; Davis, S.C. Tissue Composition of Agave americana L. Yields Greater Carbohydrates From Enzymatic Hydrolysis Than Advanced Bioenergy Crops. Front. Plant Sci. 2020, 11, 654. [CrossRef] [PubMed]

96. Láinez, M.; Ruiz, H.A.; Arellano-Plaza, M.; Martínez-Hernández, S. Bioethanol production from enzymatic hydrolysates of Agave salmiana leaves comparing S. cerevisiae and K. marxianus. Renew. Energy 2019, 138, 1127-1133. [CrossRef]

97. Krümpel, J.; George, T.; Gasston, B.; Francis, G.; Lemmer, A. Suitability of Opuntia ficus-indica (L) Mill. and Euphorbia tirucalli L. as energy crops for anaerobic digestion. J. Arid Environ. 2020, 174, 104047. [CrossRef]

98. Texco-López, A.; Álvarez-Cervantes, J.; Cadena-Ramírez, A.; Castro-Rosas, J.; Gómez-Aldapa, C.A.; Téllez-Jurado, A. Effect of hydrothermal pretreating (high pressure) and enzymatic hydrolysis of cladodes of Opuntia ficus-indica on the release of sugars and their potential use in bioethanol production. Rev. Int. De Contam. Ambient. 2019, 35, 1039-1049. [CrossRef]

99. Maceda, A.; Soto-Hernández, M.; Peña-Valdivia, C.B.; Trejo, C.; Terrazas, T. Characterization of lignocellulose of Opuntia (Cactaceae) species using FTIR spectroscopy: Possible candidates for renewable raw material. Biomass Convers. Biorefinery 2020, 912, 1-10. [CrossRef]

100. Lueangwattanapong, K.; Ammam, F.; Mason, M.; Whitehead, C.; McQueen-Mason, S.J.; Gomez, L.D.; Smith, J.A.C.; Thompson, I.P. Anaerobic digestion of Crassulacean Acid Metabolism plants: Exploring alternative feedstocks for semi-arid lands. Biores. Technol. 2020, 297, 122262. [CrossRef]

101. Kumar, A.; Ram, C. Agave biomass: A potential resource for production of value-added Products. Environ. Sustain. 2021, 4, 245-259. [CrossRef]

102. Honorato, A.; Sadhukhan, J. Annual biomass variation of agriculture crops and forestry residues, and seasonality of crop residues for energy production in Mexico. Food Bioprod. Process. 2020, 119, 1-19. [CrossRef]

103. Eisentraut, A. Sustainable Production of Second-Generation Biofuels. In Potential and Perspectives in Major Economies and Developing Countries, Information Paper; OECD/IEA, International Energy Agency: Paris, France, 2010.

104. Nobel, P.S.; Quero, E. Environmental Productivity Indices for a Chihuahuan Desert Cam Plant, Agave lechuguilla. Ecology 1986, 67, 1-11. [CrossRef]

105. Castillo-Quiroz, D.; Martínez-Burciaga, O.U.; Ávila-Flores, D.Y.; Castillo-Reyes, F.; Sánchez-Chaparro, J.D. Identification of Potential Areas for Establishment of Plantations of Agave lechuguilla Torr. in Coahuila, Mexico. Open J. For. 2014, 04, 520-526. [CrossRef]

106. Castillo-Quiroz, D.; Martínez-Burciaga, O.U.; Ríos-González, L.J.; Rodríguez-de la Garza, J.A.; Morales-Martínez, T.K.; CastilloReyes, F.; Ávila-Flores, D.Y. Determination of potential areas for Agave lechuguilla Torr. plantations for ethanol production. Acta Quim. Mex. 2014, 4, 5-12.

107. Martínez-Torres, J.; Barahona-Pérez, F.; García-Marín, P.C.; Magdub-Méndez, A.; Vergara-Yoisura, S.; Larqué-Saavedra, A.; Lappe-Oliveras, P. Ethanol production from two varieties of henequen (Agave fourcroydes Lem). GCB Bioenergy 2010, 3, 37-42. [CrossRef] 
108. SAGARPA. Inauguración de la Planta Piloto para la producción de etanol a través del Agave Mezcalero y Tequilero. 2015. Available online: http://www.sagarpa.gob.mx/Delegaciones/michoacan/boletines/Paginas/B1102015.aspx (accessed on 22 September 2021).

109. Duran, G.M.D.; Weber, B.; Jiménez, G.J.; González-Mora, E. The application of solid biofuels as a source of process energy in Mexico: Case studies using agave and coffee waste. Biofuels Bioprod. Biorefining 2021, 15, 1233-1244. [CrossRef]

110. Ramírez-Estrada, A.; Mena-Cervantes, V.Y.; Mederos-Nieto, F.S.; Pineda-Flores, G.; Hernández-Altamirano, R. Assessment and classification of lignocellulosic biomass recalcitrance by principal components analysis based on thermogravimetry and infrared spectroscopy. Int. J. Environ. Sci. Technol. 2021, 1-16. [CrossRef]

111. Duran-Cruz, V.; Hernández, S.; Ortíz, I. Evaluation of Steam Explosion Pretreatment and Enzymatic Hydrolysis Conditions for Agave Bagasse in Biomethane Production. BioEnergy Res. 2021, 1-10. [CrossRef]

112. Contreras, S.; Toha, C.J. Biogas production from a suspension of homogenized cladodes of the cactus Opuntia cacti. J. Ferment Technol. 1984, 62, 601-605.

113. Souvannasouk, V.; Shen, M.-Y.; Trejo, M.; Bhuyar, P. Biogas production from Napier grass and cattle slurry using a green energy technology. Int. J. Innov. Res. Sci. Stud. 2021, 4, 174-180.

114. Retamal, N.; Durán, J.M.; Fernández, J. Ethanol production by fermentation of fruits and cladodes of prickly pear cactus [Opuntia ficus-indica (L.) Miller]. J. Sci. Food Agric. 1987, 40, 213-218. [CrossRef]

115. Ortiz-Laurel, H.; Rössel-Kipping, D. Energy production balance for biogas generation form cactus prickly in a staged biorefinery. In Proceedings of the International conference of Agricultural Engineering, Zurich, Switzerland, 6-10 July 2014.

116. Garza, G.E.; Hernández, I.L.; Antonyan, N.; Barrón, L.C.; Vega, V.V.; Barros, M.E.; Rodríguez, C.C.; Meraz, C.D.; Ayora-Peón, R.; Pérez-Suazo, A. Production of nopal-based biogas. In Proceedings of the 2018 IISE Annual Conference, Orlando, FL, USA, 19-22 May 2018; pp. 1-5.

117. Panizio, R.M.; Calado, L.F.D.C.; Lourinho, G.; De Brito, P.S.D.; Mees, J.B. Potential of Biogas Production in Anaerobic Co-digestion of Opuntia ficus-indica and Slaughterhouse Wastes. Waste Biomass Valorization 2019, 11, 4639-4647. [CrossRef]

118. Solomon, B.D.; Banerjee, A.; Acevedo, A.; Halvorsen, K.E.; Eastmond, A. Policies for the Sustainable Development of Biofuels in the Pan American Region: A Review and Synthesis of Five Countries. Environ. Manag. 2014, 56, 1276-1294. [CrossRef] [PubMed]

119. García, C.A.; Manzini, F.; Islas, J.M. Sustainability assessment of ethanol production from two crops in Mexico. Renew. Sustain. Energy Rev. 2017, 72, 1199-1207. [CrossRef]

120. Tauro, R.; Serrano-Medrano, M.; Masera, O. Solid biofuels in Mexico: A sustainable alternative to satisfy the increasing demand for heat and power. Clean Technol. Environ. Policy 2018, 20, 1527-1539. [CrossRef]

121. Watkins, D.W.; De Moraes, M.M.G.A.; Asbjornsen, H.; Mayer, A.S.; Licata, J.; Lopez, J.G.; Pypker, T.G.; Molina, V.G.; Marques, G.F.; Carneiro, A.C.G.; et al. Bioenergy Development Policy and Practice Must Recognize Potential Hydrologic Impacts: Lessons from the Americas. Environ. Manag. 2015, 56, 1295-1314. [CrossRef]

122. Selfa, T.; Bain, C.; Moreno, R.; Eastmond, A.; Sweitz, S.; Bailey, C.; Pereira, G.S.; Souza, T.; Medeiros, R. Interrogating Social Sustainability in the Biofuels Sector in Latin America: Tensions Between Global Standards and Local Experiences in Mexico, Brazil, and Colombia. Environ. Manag. 2015, 56, 1315-1329. [CrossRef] [PubMed] 